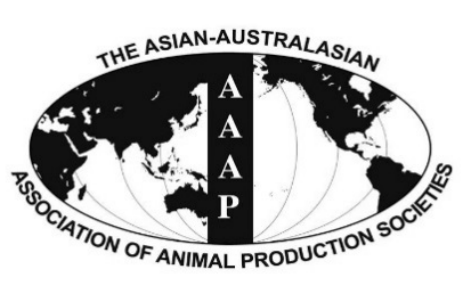

Open Access

Asian Australas. J. Anim. Sci.

Vol. 29, No. 1 : $89-99$ January 2016

http://dx.doi.org/10.5713/ajas.15.0049

www.ajas.info

pISSN 1011-2367 elSSN 1976-5517

\title{
The Differences in Chemical Composition, Physical Quality Traits and Nutritional Values of Horse Meat as Affected by Various Retail Cut Types
}

\author{
Pil Nam Seong, Kyoung Mi Park, Geun Ho Kang, Soo Hyun Cho, Beom Young Park, \\ Hyun Seok Chae, and Hoa Van Ba* \\ Animal Products and Processing Division, National Institute of Animal Science, Suwon 441-706, Korea
}

\begin{abstract}
The effects of retail cut type on chemical, quality and nutritional characteristics of horse meat were studied. Jeju female breed horses $(\mathrm{n}=9)$ at 32 -mo-old were slaughtered and the carcasses at $24 \mathrm{~h}$ post-mortem were fabricated into 10 retail cuts including: tender-loin, loin, strip-loin, shoulder-chuck-roll, shoulder-clod, top-round, outside-round, brisket, short-plate-brisket, and shank. The results revealed that all of parameters (chemical, meat quality and nutritional composition) examined significantly ( $\mathrm{p}<0.05)$ differed between the cuts. The chemical composition range (minimum to maximum) of cuts was found as such: moisture $65.06 \%$ to $71.69 \%$; protein $19.07 \%$ to $21.28 \%$; collagen $1.40 \%$ to $2.45 \%$; fat $2.56 \%$ to $12.14 \%$ and cholesterol 55.76 to $79.50 \mathrm{mg} / 100 \mathrm{~g}$. Shoulder-chuckroll had the highest $\mathrm{pH}$ and water-holding capacity, while top-round had the highest cooking loss. Shear force ranged between the cuts from $2.80 \mathrm{~kg} / \mathrm{cm}^{2}$ to $4.98 \mathrm{~kg} / \mathrm{cm}^{2}$. The $\mathrm{Cu}, \mathrm{Fe}$, and $\mathrm{Zn}$ contents ranged between the cuts from $1.52 \mathrm{mg} / \mathrm{kg}$ to $2.75 \mathrm{mg} / \mathrm{kg}, 21.25 \mathrm{mg} / \mathrm{kg}$ to $30.85 \mathrm{mg} / \mathrm{kg}$, and $16.51 \mathrm{mg} / \mathrm{kg}$ to $40.42 \mathrm{mg} / \mathrm{kg}$, respectively. Additionally, most of the cuts studied showed favorable polyunsaturated fatty acid/saturated fatty acid, n-3/n-6 and essential amino acid/non-essential amino acid ratios. (Key Words: Horse Meat, Retail Cut, Meat Quality, Nutritional Composition)
\end{abstract}

\section{INTRODUCTION}

Horses were domesticated thousands of years ago and are currently used for transport, riding and meat production purposes. Horse meat is progressively consolidating its position in the markets, which is evidenced by an increase in production and consumption of this meat type. According to Gill (2005), the amount of horse meat produced in 2004 was the highest in Asia (281,000 tons), followed by South America (84,000 tons) and Western Europe (64,000 tons. According to the recent data from the Food and Agricultural Organization (FAO, 2010), China produced 170,848 tons of horse meat to become one of the largest horse meat producers in the world. Besides, from 2006 to 2010, U.S horse exports for slaughter increased by $148 \%$ and $660 \%$ to Canadian and Mexican markets, respectively. In recent years, additionally, a demand for alternative meat compared

\footnotetext{
* Corresponding Author: Hoa Van Ba. Tel: +82-31-290-1699, Fax: +82-31-290-1697, E-mail: hoavanba@jbnu.ac.kr Submitted Jan. 15, 2015; Revised Mar. 5, 2015; Accepted May 26, 2015
}

to conventional meat is increasing and horse meat plays a major role in this context and is claimed as "dietetic" meat (Lorenzo et al., 2014).

Regarding the nutritional aspect, the horse meat is a good source of important nutrients, as characterized by high protein and trace-minerals contents, higher polyunsaturated fatty acids (PUFA) content and PUFA/saturated fatty acid (SFA) ratio in comparison to the other conventional meats such as beef and pork (Sarriés and et al., 2006; Tateo et al., 2008; Lorenzo et al., 2014). In addition, regular consumption of this meat type may contribute to reduced total and low-density lipoprotein cholesterol intakes and improve omega-3 index, docosahexaeneoic acid (C22:3n-6) and iron status (Del Bo et al., 2013). Moreover, horses also show high suitability for meat production, reflecting good dressing percentages very close to $70 \%$ in meat yield (Juarez et al., 2009).

So far, the two main horse categories which commonly slaughtered for human consumption are; i) animals that come from drought races or saddle horses, often at the end of their career (Badiani and Manfredini, 1994; Tateo et al., 
2008), and ii) foals that are usually weaned on natural pasture and immediately finished in feedlot on concentrates and hay or straw until target slaughter weight (Sarriés and Beriain, 2005; Sarriés et al., 2006; Franco et al., 2011;2013; Lorenzo et al., 2013; Franco and Lorenzo, 2014). In general, the animals belonging to the second category are usually slaughtered at younger age usually from 6 to 24-mo-old, while horses with age of around 30-mo-old similar to the slaughter age of bovine steers and heifers (Campo et al., 2010) have not been studied for their meat quality characteristics.

In the meat industry, in case of beef for example, after slaughter and deboning, the carcass is usually made into commercial beef cuts (Maeno et al., 2014), with the retail price differing considerably among these cuts, for instance, from US\$4.97/100 $\mathrm{g}$ for brisket to US\$11.57/100 $\mathrm{g}$ for tender-loin (JMI, 2010). Although the scientific information regarding the horse meat quality is available, most of the researchers only focused on evaluating the influences of exterior factors (e.g., as sex, breed and diet), and more noticeably they only used the longissimus dorsi muscle as a representative sample in their studies to assess the effects of aforementioned factors on the quality characteristics of this meat type. Whereas, for the other remaining muscles/or cuts that account for a significant weight ratio and contribute to the determination of final economic value of a horse carcass, little attention has been paid to evaluating the variations in the quality characteristics between the cuts. In order to grow the consumption and promote the trade activities of horse meat more detailed studies on the factors affecting the quality of this meat type are required. Therefore, the aim of this study was to assess the influence of retail cut type on the technological quality traits, nutritional quality and sensory characteristics of horse meat slaughtered at 32-moold.

\section{MATERIALS AND METHODS}

\section{Animals and sample preparation}

Jeju female crossbreed horses $(n=9)$ obtained from a local farm in Jeju province, Korea were used in the present research. Animals were reared with their mothers on pasture and kept suckling until the weaning age (6-mo-old). After weaning, the animals were fed ad libitum with a dried grass (Tall fescue) diet supplemented with 1.6\% concentrate until 32-mo-old. The basal composition of the concentrate diet supplemented in the present study contained $17.12 \%$ crude protein, $5.02 \%$ crude fat, $6.30 \%$ crude fiber, $3.59 \mathrm{cal} / \mathrm{g}$, $11.80 \%$ moisture, $0.26 \% \mathrm{Ca}, 0.07 \% \mathrm{P}, 0.06 \% \mathrm{Mg}, 1.33 \% \mathrm{~K}$, $0.03 \% \mathrm{Na}, \mathrm{Cu}(7.81 \mathrm{mg} / \mathrm{kg}), \mathrm{Fe}(59.7 \mathrm{mg} / \mathrm{kg}), \mathrm{Mn}(89.4$ $\mathrm{mg} / \mathrm{kg})$, and $\mathrm{Zn}(27.8 \mathrm{mg} / \mathrm{kg})$. The average live weights of horses at slaughter were $360 \pm 20 \mathrm{~kg}$. The animals were stunned with a captive bolt, slaughtered and dressed. On completion of dressing, each carcass was split and then chilled for $24 \mathrm{~h}$ in a chilling room $\left(2^{\circ} \mathrm{C} \pm 2^{\circ} \mathrm{C}\right)$. At $24 \mathrm{~h}$ postmortem, the carcass sides were transferred to a cutting room where 10 retail cuts were obtained from both carcass sides of each animal according to the Standard for retail cut trading (MFDS, 1996) and the Korean carcass grading system (1998). The cuts (with their representative muscles) were: loin (longissimus dorsi muscle from $1^{\text {st }}$ to 13th thoracic vertebrae), strip-loin (longissimus dorsi muscle from $1^{\text {st }}$ to 5 th lumbar vertebrae), shoulder-chuck-roll (splenius and ventral serratus muscles), shank (extensor digitorum longus and extensor digitorum pedis lateralis muscles), outside-round (biceps femoris and vastus lateralis muscles), tender-loin (psoas major and psoas minor muscles), shoulder-clod (supraspinatus and triceps brachii muscles), brisket (cranial superficial pectoral and brachiocephalicus muscles), top-round (semimembranosus and semitendinosus muscles) and short-plate-brisket (obliquus externus abdominis, transversus abdominis and rectus abdominis). Immediately following, the cuts were placed in plastic bags and transferred to the Laboratory of Meat Science, where the cuts were carefully trimmed of all visual fats and connective tissue. Thereafter, the cuts from the right side of each carcass were ground using a meat chopper (model SMC-12, SL Co., Incheon, Korea) and then used for analysis of proximate composition, whereas those from the opposite sides of carcasses were cut into subsamples sizes depending on the type of analysis in the following order: technological quality traits $(\mathrm{pH}$, waterholding capacity [WHC] and color+cooking loss+shear force) and nutritional composition (fatty acid-amino acidmineral contents). For the samples which used for nutritional composition analysis were placed in plastic bags, vacuum-packaged and stored at $-20^{\circ} \mathrm{C}$ until use.

\section{Proximate composition analysis}

The proximate composition such as crude fat, crude protein, moisture and collagen contents in the cuts were analyzed using a Food Scan Lab 78810 (Foss Tecator Co., Ltd., Hillerod, Denmark) according to the method of the Association of Official Analytical Chemists (AOAC, 2006). To determine calories, the sample was homogenized in a blender (HMF 3160S, Hanil Co., Seoul, Korea), and then the homogenate was used for caloric measurement with a calorimeter (model 1261, Parr instrument, Moline, IL, USA). Calories were expressed as $\mathrm{cal} / \mathrm{g}$ of the sample. Cholesterol content was determined according to the method of Rhee et al. (1982).

\section{pH measurement}

The $\mathrm{pH}$ values of cuts were determined with a $\mathrm{pH} * \mathrm{~K} 21$ 
(NWK-Technology GmbH, Kaufering, Germany) equipped with a stainless steel, solid-state probe, ensuring that the probe was inserted deep into the muscle tissue. Prior to use, the $\mathrm{pH}$ meter was calibrated with $\mathrm{pH} 4$ and 7 standards (NWK Technology., Bayerntrasse, Kaufering, Germany). The $\mathrm{pH}$ mean values of each sample were the average of the two readings.

\section{Water-holding capacity}

The WHC of the cuts was measured using the method as described by Sakata et al. (1993).

\section{Color, cooking loss and Warner-Bratzler shear force value measurement}

The color, cooking loss and Warner-Bratzler shear force (WBSF) were measured on the same steak of each cut. Briefly, color was determined on freshly cut surface of steak samples at five different locations after $30 \mathrm{~min}$ of blooming using a CR-400 chroma meter (Minolta Co., Osaka, Japan). The instrument was standardized with a provided white plate $(\mathrm{Y}=86.3, \mathrm{X}=0.3165$ and $\mathrm{y}=0.3242)$ prior to use. The color values were expressed according to the Commission International de l'Eclairage (CIE) system (CIE, 1976) and reported as $\mathrm{L}^{*}$ (lightness), $\mathrm{a}^{*}$ (redness), and $\mathrm{b}^{*}$ (yellowness), chroma and hue angle $\left(\mathrm{h}^{\circ}\right)$. In which the chroma and hue angle were calculated as $\left(a^{* 2}+b^{* 2}\right)^{0.5}$ and $\tan ^{-1}\left(b^{*} / a^{*}\right)$, respectively.

After color measurement, the steak samples were used to determine cooking loss and WBSF. The cooking loss and WBSF of horse meat cuts were measured using the method as described by Hwang et al. (2004) with minor modifications. Briefly, steaks (3.0-cm thick) of about $300 \mathrm{~g}$ were placed in plastic bags, put in a pre-heated $72^{\circ} \mathrm{C}$ water bath (Water-bath BS-21, Jeiotech Co., Daejeon, Korea) and then cooked for a further $30 \mathrm{~min}$ after their core temperature had reached $70^{\circ} \mathrm{C}$. The core temperature of samples was monitored using a copper-constantan thermocouple attached to a thermo recorder (Model TR-71U; T \& D Corp., Tokyo, Japan). The cooked samples were immediately cooled in a circulatory water bath set at $18^{\circ} \mathrm{C}$ for $30 \mathrm{~min}$ to reach a core temperature below $30^{\circ} \mathrm{C}$, removed from the bags and then re-weighed to determined cooking loss. For the WBSF measurement, 6 strips core samples that had an average diameter of 0.5 inches and length of at least $2 \mathrm{~cm}$ were removed parallel to the muscle fiber direction of each sample using a 0.5 inch metal corer. The WBSF values were obtained by completely cutting the 6 representative strips of each sample in an Instron Universal Testing Machine (Model 4465, Instron Corp, High Wycombe, UK) using a crosshead speed of $200 \mathrm{~mm} / \mathrm{min}$ and a $40 \mathrm{~N}$ load cell.

\section{Fatty acid composition}

Total lipids were extracted according to the methods of
Folch et al. (1957), and Morrison and Smith (1964). Subsequently, the fatty acids were analyzed using a gas chromatograph system (Varian star 3600, Varian, Inc., City, CA, USA) equipped with flame ionization detector and Omegawax 205 fused-silica bond capillary column (30 $\mathrm{m} \times 0.32 \mathrm{~mm} \times 0.25 \mu \mathrm{m}$ film thickness). The initial and final temperatures of the oven were $140^{\circ} \mathrm{C}$ and $230^{\circ} \mathrm{C}$, respectively. The injector port and detector temperatures were $250^{\circ} \mathrm{C}$ and $260^{\circ} \mathrm{C}$ respectively. Individual fatty acids were confirmed on the basis of retention time through comparison with a commercially available mixture of fatty acids (PUFA No.2-Animal Source, Supelco, Bellefonte, PA, USA). The fatty acid profile was expressed as percentage of individual fatty acids identified.

\section{Mineral contents}

Mineral contents were determined by following the method of Matilainen and Tummavuori (1996). Briefly, five grams of each sample was destroyed by dry ashing in a microwave ashing oven (MAS 7000, CEM Corp., Mathews, $\mathrm{NC}$, USA) for $12 \mathrm{~h}$ with a final temperature of $600^{\circ} \mathrm{C}$. The ash content was dissolved in $10 \mathrm{~mL}$ of $37 \% \mathrm{HCl}$ and distilled water $(1: 1 \mathrm{v} / \mathrm{v})$ solution and was then filtered through Whatman filter paper (No.6) (AEC scientific Co., Seoul, Korea). Minerals including Na (selected wavelength $588.9 \mathrm{~nm}), \mathrm{K}(766.5 \mathrm{~nm}), \mathrm{Ca}(422.7 \mathrm{~nm}), \mathrm{Mg}$ (285 nm), P $(470 \mathrm{~nm})$, Fe $(248.3 \mathrm{~nm})$, and Zn (213.9 nm), Mn (279.5 $\mathrm{nm}), \mathrm{Cu}(324.7 \mathrm{~nm})$ and $\mathrm{Cr}(357.9 \mathrm{~nm})$ were determined by atomic emission spectrophotometer ICP-OES (Spectro, Boschstr, Kleve, Germany). A calibration curve was prepared for each element.

\section{Amino acid contents}

The sample preparation for amino acids analysis was performed according to the procedure of Aristoy and Toldra (1991). Briefly, the samples were hydrolyzed with $6 \mathrm{~N} \mathrm{HCl}$ solution for $24 \mathrm{~h}$ at $110^{\circ} \mathrm{C}$. The hydrolyzed samples were concentrated at $50^{\circ} \mathrm{C}$ and then diluted with $50 \mathrm{~mL}$ of $0.2 \mathrm{~N}$ sodium citrate buffer ( $\mathrm{pH} 2.2)$, and finally were filtered through $0.45 \mu \mathrm{m}$ filters (Millipore Corp., Biedford, MA, USA). To avoid the oxidation of cysteine and methionine, $20 \mathrm{~mL}$ of performic acid was added to each sample as a protective agent before the acid hydrolysis. The amino acids were then determined by applying the filtrates $(30 \mu \mathrm{L}$ each) to an amino acid analyzer (model 8900A) equipped with an exchange column $(4.6 \times 60 \mathrm{~mm})$ (Hitachi, Japan). The separation and detection of amino acids were carried out using the method as described by Moya et al. (2001).

\section{Statistical analysis}

The effect of different cut types on the chemical, technological quality and nutritional characteristics of horse meat was analyzed using the General Linear Model 
procedure of SAS (Statistic Analysis System Institute, Cary, NC, USA, 2007) considering the cut type as the main effect. Mean values of the measurements were compared using the Duncan's multiple-range test at the significance level of 0.05 .

\section{RESULTS AND DISCUSSION}

\section{Effect of cut type on proximate composition}

The mean values for the proximate composition traits of horse meat cuts are shown in Table 1. The cut type significantly $(\mathrm{p}<0.05)$ affected all of the proximate compositions determined with exception of calorie content. The moisture content ranged between the cuts from $65.06 \%$ to $71.69 \%$, and were lower than the values $(74.78 \%$ to $77.40 \%$ ) reported in the literature for various muscles of foals slaughtered at younger ages, 9- and 15-mo-old (Franco et al., 2011; Lorenzo et al., 2013). The protein contents in loin $(21.09 \%)$, strip-loin $(21.44 \%)$, top-round $(21.28 \%)$ and shank $(20.99 \%)$ were not significantly different from each other $(p>0.05)$ but they were significantly $(p<0.05)$ higher than those in the other remaining cuts such as shoulder-clod $(20.10 \%)$ and brisket $(20.38 \%)$. The cuts with the lowest protein contents were shoulder-chuck-roll $(19.69 \%)$ and short-plate-brisket (19.07\%). Similar to our results, those of Tateo et al. (2008) showed that protein content in foal meat was significantly affected by the muscle type. Sarriés and Beriain (2005) reported lower protein levels $(19.90 \%$ to $20.59 \%)$ in longissimus dorsi muscle of 16- and 24-mo-old foals, similarly Franco et al. (2011) also reported lower levels ( $20.44 \%$ to $20.61 \%$ ) in longissimus dorsi muscle of 9-12mo-old foals compared to those in loin as well as other cuts in our study. The difference in protein contents could be due to the differences in slaughter age and breed between the studies. For the collagen content, shank had the highest level $(2.45 \%)$, followed by shoulder-chuck-roll $(2.1 \%)$, shoulder-clod $(1.76 \%)$ and other remaining cuts $(\mathrm{p}<0.05)$, however, no difference in collagen content occurred between the tender-loin, loin, strip-loin, top-round and outside-round $(p>0.05)$. The variations in collagen contents could be due to the difference in physical activity in relation to the anatomical position between the cuts. The fat content ranged between the cuts from $2.56 \%$ to $12.14 \%$, in which short-plate-brisket had the highest fat content, shoulder-clod had lower, and top-round had the lowest level $(p<0.05)$. Whereas, no statistical difference $(p>0.05)$ was observed between the tender-loin, loin, strip-loin, shoulder-chuck-roll and brisket for the fat content. In general, the fat levels in all cuts examined in this study were higher than those reported in the literature for longissimus dorsi, semitendinosus, semimembranosus, psoas major and minor, biceps femoris as well as triceps brachii muscles of 9-24mo-old foals (Franco et al., 2013; Franco and Lorenzo, 2014). According to the previous reports which indicated that the meat with higher fat content or marbling level usually has better eating quality and is more preferred by consumers (Maeno et al., 2014). When compared to the fat levels in muscles of horses slaughtered at younger age as cited above, all cuts in the present study had higher fat contents.

High cholesterol intake has been associated with an elevated risk of cardiovascular diseases such as coronary heart disease and high blood pressure as well as diabetes (Kratz, 2005). The cholesterol content in meat as a whole, therefore, becomes a concern of consumers. The outcome of our analysis showed that the highest cholesterol content was found in tender-loin $(79.50 \mathrm{mg} / 100 \mathrm{~g}$ sample) and the lowest was found in short-plate-brisket $(55.76 \mathrm{mg} / 100 \mathrm{~g}$ sample), and no difference in cholesterol level occurred between the other remaining cuts. In contrast to our finding, Lorenzo and Pateiro (2013) found no significant differences in cholesterol levels between muscles of 15-mo-old foals. In general, the cholesterol levels in some cuts such as loin, strip-loin, shoulder-clod, brisket, short-plate-brisket and shank were almost equal whereas those in some cuts such as tender-loin, shoulder-chuck-roll, top-round and outsideround were higher than the cholesterol levels reported for

Table 1. Proximate composition (mean \pm standard error) of horse meat as affected by cut type

\begin{tabular}{|c|c|c|c|c|c|c|}
\hline Item & Moisture (\%) & Protein $(\%)$ & Collagen $(\%)$ & Fat (\%) & Cholesterol (mg/100 g) & Calorie (cal/g) \\
\hline Tender-loin & $70.35 \pm 1.71^{\mathrm{abcd}}$ & $20.63 \pm 0.68^{\mathrm{bc}}$ & $1.57 \pm 0.30^{\text {cde }}$ & $5.15 \pm 1.75^{\text {cde }}$ & $79.50 \pm 10.05^{\mathrm{a}}$ & $1,516.40 \pm 730$ \\
\hline Loin & $69.07 \pm 1.95^{\mathrm{d}}$ & $21.09 \pm 1.20^{\mathrm{ab}}$ & $1.40 \pm 0.41^{\mathrm{e}}$ & $5.27 \pm 2.97^{\mathrm{cd}}$ & $63.16 \pm 6.56^{\mathrm{ab}}$ & $1,754.60 \pm 867$ \\
\hline Strip-loin & $69.10 \pm 1.54^{\mathrm{d}}$ & $21.44 \pm 0.73^{\mathrm{a}}$ & $1.48 \pm 0.22^{\mathrm{de}}$ & $5.18 \pm 1.85^{\text {cde }}$ & $60.14 \pm 7.33^{\mathrm{ab}}$ & $1,772.80 \pm 130$ \\
\hline Shoulder-chuck-roll & $70.16 \pm 1.6^{\mathrm{bcd}}$ & $19.69 \pm 0.67^{\mathrm{e}}$ & $2.10 \pm 0.20^{\mathrm{b}}$ & $5.30 \pm 1.11^{\mathrm{cd}}$ & $75.42 \pm 5.01^{\mathrm{ab}}$ & $1,832.40 \pm 111$ \\
\hline Shoulder-clod & $69.17 \pm 2.05^{\mathrm{d}}$ & $20.10 \pm 0.57^{\mathrm{de}}$ & $1.76 \pm 0.22^{\mathrm{c}}$ & $5.56 \pm 3.00^{\mathrm{b}}$ & $65.14 \pm 10.53^{\mathrm{ab}}$ & $1,276.60 \pm 935$ \\
\hline Top-round & $71.69 \pm 0.85^{\mathrm{a}}$ & $21.28 \pm 0.46^{\mathrm{a}}$ & $1.58 \pm 0.15^{\text {cde }}$ & $2.56 \pm 0.59^{\mathrm{f}}$ & $72.36 \pm 9.57^{\mathrm{ab}}$ & $1,605.80 \pm 130$ \\
\hline Outside-round & $70.69 \pm 0.99^{\mathrm{abc}}$ & $20.7 \pm 0.38^{\mathrm{bc}}$ & $1.60 \pm 0.18^{\text {cde }}$ & $3.65 \pm 0.97^{\mathrm{def}}$ & $69.44 \pm 11.51^{\mathrm{ab}}$ & $1,759.00 \pm 38$ \\
\hline Brisket & $69.60 \pm 1.82^{\mathrm{cd}}$ & $20.38 \pm 0.56^{\mathrm{cd}}$ & $1.72 \pm 0.26^{\mathrm{c}}$ & $5.25 \pm 1.47^{\mathrm{cd}}$ & $61.02 \pm 16.02^{\mathrm{ab}}$ & $1,993.80 \pm 185$ \\
\hline Short-plate-brisket & $65.06 \pm 2.62^{\mathrm{e}}$ & $19.07 \pm 0.77^{\mathrm{f}}$ & $1.64 \pm 0.29^{\mathrm{cd}}$ & $12.14 \pm 2.77^{\mathrm{a}}$ & $55.76 \pm 28.45^{\mathrm{b}}$ & $2,171.60 \pm 115$ \\
\hline Shank & $71.41 \pm 2.22^{\mathrm{ab}}$ & $20.99 \pm 0.72^{\mathrm{ab}}$ & $2.45 \pm 0.53^{\mathrm{a}}$ & $3.41 \pm 2.05^{\mathrm{ef}}$ & $63.18 \pm 24.9^{\mathrm{ab}}$ & $1,608.40 \pm 203$ \\
\hline
\end{tabular}

\footnotetext{
${ }^{a-f}$ Means with different superscripts in the same column differ significantly $(\mathrm{p}<0.05)$
} 
various muscles of 6 to 24 month old foals (Lorenzo et al., 2014). The recommended maximum cholesterol intake is $300 \mathrm{mg}$ per day (American Heart Association, 2008), therefore, for example; consuming $200 \mathrm{~g}$ of horse loin in this study represents a cholesterol intake of $126.32 \mathrm{mg}$, which corresponds to approximate $42 \%$ of the recommended maximum daily cholesterol intake.

\section{Effect of cut type on color}

Our results depict a significant difference in color traits between the cuts (Table 2). Particularly, the lightness values ranging between the cuts from 32.61 to 36.56 , were lower than the values (41.07 to 41.19) reported for longissimus dorsi muscle of 9 and 12-mo-old female foals (Franco et al., 2011), and also lower than the values reported for the longissimus dorsi, semitendinosus, semimembranosus, psoas major and minor, and biceps femoris muscles of 15mo-old male and female foals (Lorenzo et al., 2013). For the CIE a* (redness), values ranged between the cuts from 16.01 to 18.55 in this study. In the comparison between cuts for the redness, shoulder-chuck-roll had the highest value, tender-loin and short-plate-brisket had lower values whereas top-round had the lowest value $(\mathrm{p}<0.05)$. The differences in intensity of redness may be explained as the difference in anatomical positions which differ in myoglobin contents between the cuts. The finding of our study agrees well with those of Tateo et al. (2008) and Lorenzo et al. (2013), who showed a significant effect of muscle type on the color of horse meat. However, the intensity of redness of the cuts in our study gave a*-values higher than the values (9.38 to 11.92) of various muscles of 11-mo-old female foals (Tateo et al., 2008), and also higher than the values (10.40 to 15.60) reported for longissimus dorsi muscle of 16-24-mo-old female foals (Sarries and Beriain, 2006). Those contrasting results may be due to the slaughter age difference, with lower myoglobin content in muscles for the earlier age at slaughtering compared with that for the older age at slaughtering (Tateo et al., 2008). Similarly, Sarries and Beriain (2005) found higher $a^{*}$ - values in longissimus dorsi and rectus abdominis muscles of 24-mo-old foals compared with those in the same muscles of 16-mo-old counterparts. Regarding CIE b* (yellowness), values ranged between the cuts from 5.99 to 7.65 , in which the tender-loin and shoulder-chuck-roll had the highest values (7.65 and 7.61, respectively) whereas shoulder-clod had the lowest value (5.99). Previous studies reported that factors such as slaughter age, sex and breed significantly affected the yellowness values of horse meat (Sarries and Beriain, 2006; Juarez et al., 2009). In our study we kept all the above mentioned factors constant for the selected animals but still a significant difference in the yellowness value between the cuts was observed, which was probably due to the difference in fatty acids composition of the intramuscular fat between the cuts. For the chroma and hue angle, values ranged between the cuts from 17.24 to 20.09 and 19.76 to 23.47 , respectively in the present study. In comparison between the cuts for these two colorimetric traits, shoulder-chuck-roll had the highest chroma value and tender-loin had the highest hue angle value. Color is an important quality trait which considerably influences the salability, appearance and attractiveness of meat to consumers (Faustman and Cassens, 1990). However, horse meat is rich in myoglobin with high ability to combine with oxygen, which accelerates the oxidation of the bright red oxymyoglobin to brown metmyoglobin (Lorenzo et al., 2014), and finally oxygen reduces the stability of the red color as well as shortens the shelf-life of horse meat (Badiani and Manfredini, 1994). Therefore, some optimal solutions such as using suitable packaging or storage techniques (Sekar et al., 2006) to enhance color stability of this meat type are needed.

\section{Effect of cut type on PH, water holding capacity, cooking loss and shear force value}

Some technological quality traits such as $\mathrm{pH}$, WHC, cooking loss and shear force of cuts are presented in Table 3. With regard to the meat $\mathrm{pH}$, which showed a significant $(p<0.05)$ difference among the cuts in which shoulder-

Table 2. Color characteristics (mean \pm standard error) of horsemeat as affected by cut type

\begin{tabular}{|c|c|c|c|c|c|}
\hline Cuts & CIE L* & CIE a* & CIE b* & Chroma & Hue angle \\
\hline Tender-Loin & $35.05 \pm 1.33^{\mathrm{cd}}$ & $17.52 \pm 1.54^{\mathrm{b}}$ & $7.65 \pm 1.64^{\mathrm{a}}$ & $19.17 \pm 1.73^{\mathrm{b}}$ & $23.47 \pm 4.39^{\mathrm{a}}$ \\
\hline Loin & $34.73 \pm 1.75^{\mathrm{cde}}$ & $17.11 \pm 1.38^{\mathrm{bc}}$ & $6.75 \pm 0.91^{\mathrm{bc}}$ & $18.4 \pm 1.52^{\mathrm{bcd}}$ & $21.50 \pm 2.10^{\mathrm{cd}}$ \\
\hline Strip-loin & $34.01 \pm 1.91^{\mathrm{efg}}$ & $16.58 \pm 1.23^{\mathrm{cd}}$ & $6.47 \pm 0.79^{\text {cd }}$ & $17.8 \pm 1.37$ de & $21.27 \pm 1.65^{\mathrm{cd}}$ \\
\hline Shoulder-chuck-roll & $34.37 \pm 2.03^{\text {cdef }}$ & $18.55 \pm 2.37^{\mathrm{a}}$ & $7.61 \pm 2.05^{\mathrm{a}}$ & $20.09 \pm 2.85^{\mathrm{a}}$ & $21.95 \pm 3.79^{b c}$ \\
\hline Shoulder-clod & $33.51 \pm 1.53^{\mathrm{fgh}}$ & $16.62 \pm 1.59^{\mathrm{cd}}$ & $5.99 \pm 0.94^{\mathrm{d}}$ & $17.68 \pm 1.74^{\mathrm{de}}$ & $19.76 \pm 2.07^{\mathrm{e}}$ \\
\hline Top-round & $36.02 \pm 2.91^{\mathrm{ab}}$ & $16.01 \pm 1.14^{\mathrm{d}}$ & $6.32 \pm 1.19^{\mathrm{cd}}$ & $17.24 \pm 1.22^{\mathrm{e}}$ & $21.50 \pm 3.76^{\mathrm{cd}}$ \\
\hline Outside-round & $32.61 \pm 2.00^{\mathrm{h}}$ & $16.7 \pm 1.00^{\mathrm{cd}}$ & $6.41 \pm 1.01^{\mathrm{cd}}$ & $17.91 \pm 1.12^{\mathrm{de}}$ & $20.95 \pm 2.77^{\mathrm{cde}}$ \\
\hline Brisket & $33.11 \pm 2.03^{\mathrm{gh}}$ & $17.18 \pm 1.58^{\mathrm{bc}}$ & $6.48 \pm 1.10^{\text {cd }}$ & $18.38 \pm 1.75^{\mathrm{bcd}}$ & $20.58 \pm 2.60^{\text {cde }}$ \\
\hline Short-plate-brisket & $36.56 \pm 1.91^{\mathrm{a}}$ & $17.49 \pm 2.06^{\mathrm{b}}$ & $6.88 \pm 1.67^{\mathrm{bc}}$ & $18.83 \pm 2.43^{\mathrm{bc}}$ & $21.25 \pm 3.22^{\mathrm{cd}}$ \\
\hline Shank & $35.19 \pm 2.61^{b c}$ & $16.56 \pm 1.73^{\mathrm{cd}}$ & $6.44 \pm 1.77^{\mathrm{cd}}$ & $17.82 \pm 2.05^{\mathrm{de}}$ & $21.00 \pm 4.55^{\mathrm{cde}}$ \\
\hline
\end{tabular}

CIE, Commission International de l'Eclairage.

${ }^{a-f}$ Means with different superscripts in the same column differ significantly $(p<0.05)$. 
Table 3. Ultimate $\mathrm{pH}$, water holding capacity (WHC), cooking loss and shear force (mean \pm standard error) of horsemeat as affected by cut type

\begin{tabular}{lllll}
\hline Cut type & $\mathrm{pH}$ & WHC (\%) & Cooking loss (\%) & WBSF (kgf) \\
\hline Tender-loin & $5.68 \pm 0.06^{\mathrm{d}}$ & $53.57 \pm 1.38^{\mathrm{ab}}$ & $23.38 \pm 3.32^{\mathrm{cd}}$ & $2.80 \pm 0.28^{\mathrm{h}}$ \\
Loin & $5.80 \pm 0.08^{\mathrm{b}}$ & $53.04 \pm 1.90^{\mathrm{abc}}$ & $24.57 \pm 2.93^{\mathrm{bcd}}$ & $3.40 \pm 0.67^{\mathrm{fg}}$ \\
Strip-loin & $5.58 \pm 0.05^{\mathrm{f}}$ & $54.77 \pm 2.36^{\mathrm{a}}$ & $25.48 \pm 2.78^{\mathrm{abcd}}$ & $3.67 \pm 0.67^{\mathrm{ef}}$ \\
Shoulder-chuck -roll & $5.95 \pm 0.15^{\mathrm{a}}$ & $54.44 \pm 1.99^{\mathrm{ab}}$ & $25.83 \pm 4.07^{\mathrm{abcd}}$ & $3.28 \pm 0.79^{\mathrm{g}}$ \\
Shoulder-clod & $5.74 \pm 0.10^{\mathrm{c}}$ & $50.42 \pm 0.79^{\mathrm{de}}$ & $25.98 \pm 4.72^{\mathrm{abcd}}$ & $3.77 \pm 0.96^{\mathrm{de}}$ \\
Top-round & $5.60 \pm 0.11^{\mathrm{ef}}$ & $51.20 \pm 1.65^{\mathrm{cde}}$ & $27.40 \pm 3.61^{\mathrm{a}}$ & $3.98 \pm 0.74^{\mathrm{cde}}$ \\
Outside-round & $5.62 \pm 0.07^{\mathrm{ef}}$ & $50.79 \pm 1.07^{\mathrm{de}}$ & $26.98 \pm 1.90^{\mathrm{abc}}$ & $4.15 \pm 0.97^{\mathrm{bc}}$ \\
Brisket & $5.66 \pm 0.1^{\mathrm{ed}}$ & $51.83 \pm 1.44^{\mathrm{bcd}}$ & $26.27 \pm 4.24^{\mathrm{abc}}$ & $4.44 \pm 1.34^{\mathrm{b}}$ \\
Short-plate-brisket & $5.70 \pm 0.13^{\mathrm{cd}}$ & $50.10 \pm 2.34^{\mathrm{de}}$ & $22.27 \pm 2.87^{\mathrm{d}}$ & $3.98 \pm 1.05^{\mathrm{cde}}$ \\
Shank & $5.85 \pm 0.15^{\mathrm{b}}$ & $53.90 \pm 2.04^{\mathrm{ab}}$ & $24.55 \pm 4.22^{\mathrm{bcd}}$ & $4.98 \pm 0.94^{\mathrm{a}}$ \\
\hline WBSF, Ward
\end{tabular}

WBSF, Warner-Bratzler shear force.

${ }^{a-f}$ Means with different superscripts in the same column differ significantly $(p<0.05)$.

chuck-roll had the highest value (5.95); followed by shank (5.85), loin (5.80), shoulder-clod (5.74) and short-platebrisket (5.70) while the lowest values were in trip-loin (5.58), top-round (5.60), outside-round (5.62) and brisket (5.66). These differences in $\mathrm{pH}$ values could be due to the differences in physical activity, levels of glycogen stored and its degradation rate among the cuts. The values of meat $\mathrm{pH}$ in some cuts such as strip-loin, top-round, outside-round and brisket were almost similar whereas those of loin, shoulder-chuck-round, shoulder-clod and shank were higher than the values (5.61 to 5.66) reported for various muscles of 15-mo-old foals (Franco and Lorenzo, 2014). Contrary to our results, these authors and Tateo et al. (2008) reported no difference in $\mathrm{pH}$ values among the muscles, while Litwinczuk et al. (2008) found higher $\mathrm{pH}$ value in longissimus lumborum (5.72) than in semitendinosus muscle (5.69) of 10 years old horses. These contrasting results could be explained due to the differences with respect to the pre-slaughter state of the animal (e.g., stress degree and starvation duration), feeding/or diet and slaughter age between the studies.

The results of WHC evaluation showed significant differences among the cuts, ranging from $49.44 \%$ to $54.77 \%$. The cuts that had the highest capacity to hold water were strip-loin $(54.77 \%)$, tender-loin $(53.57 \%)$ and shank $(53.90 \%)$ whereas the cut with the lowest WHC value was short-plate-brisket. Our findings agree well with that of Tateo et al. (2008), who showed a significant effect of muscle type on WHC of meat from 11-mo-old foals. When compared to the WHC values reported for longissimus dorsi muscle $(18.19 \%$ to $20.04 \%)$ of foals slaughtered at $6-$, 11 and 18-mo-old (Palo et al., 2013), or biceps femoris $(36.87 \%)$, longissimus dorsi $(33.56 \%)$, rectus femoris (39.15\%), semimembranosus (39.74\%) and semitendinosus $(32.50 \%)$ muscles of 11-mo-old foals (Tateo et al., 2008), all cuts studied had higher WHC values. Previous studies on pork, beef and chicken (Huff-Lonergan and Lonergan, 2005) showed an association of ultimate $\mathrm{pH}$ with WHC, particularly the meat with higher ultimate $\mathrm{pH}$ value usually has higher WHC. In the present study, therefore, the differences in WHC values could be explained partly due to the $\mathrm{pH}$ differences between the cuts.

With regard to cooking loss, our results showed that the loss level $(27.40 \%)$ in top-round was higher $(\mathrm{p}<0.05)$ than that $(23.38 \%)$ in tender-loin but not significantly ( $p>0.05)$ different with those from other cuts such as strip-loin, shoulder-chuck-roll, shoulder-clod, out-side-round and brisket. The cut which showed the lowest cooking loss level was short-plate-brisket (22.27\%). It has been found that fat content is one of the factors affecting the cooking loss for instance; beef with higher fat level had lower cooking loss (Han et al., 1996). Therefore, the results indicating the differences in cooking loss levels could be due to the fat differences between the cuts (Table 1). On the other hand, the cooking loss levels ranged between the cuts from $22.27 \%$ to $27.40 \%$ in the present study were almost similar the values $(22.67 \%$ to $27.36 \%)$ reported for various muscles of 11-mo-old foals cooked to an internal temperature of $70^{\circ} \mathrm{C}$ for $3 \mathrm{~min}$ (Tateo et al., 2008), but higher than the values $(13.89 \%$ to $20.77 \%)$ reported for various muscles of 15-mo-old foals cooked until the core temperature reached $70^{\circ} \mathrm{C}$ (Lorenzo et al., 2013; Franco and Lorenzo, 2014). It has been well established that the cooking loss increases as the cooking temperature increased (Lepetit et al., 2000), therefore, the differences in loss levels could be due to the differences in cooking conditions between studies.

The WBSF evaluation revealed significant differences among the cuts with the values ranged between the cuts from 2.80 to $4.98 \mathrm{~kg} / \mathrm{cm}^{2}$. The cut with the highest WBSF value was shank $\left(4.98 \mathrm{~kg} / \mathrm{cm}^{2}\right)$, brisket had lower value $\left(4.44 \mathrm{~kg} / \mathrm{cm}^{2}\right)$ whereas tender-loin presented the lowest value $\left(2.80 \mathrm{~kg} / \mathrm{cm}^{2}\right)(\mathrm{p}<0.05)$. The variations in shear force values could be due to the differences in anatomical position and physical activity which finally affect the 
collagen contents (Table 1) between the cuts. According to the tenderness categories classification proposed by Belew et al. (2003), the horse meat cuts within this investigation can be considered as "very tender" (WBSF $<3.2 \mathrm{~kg}$ ) was the tender-loin; the cuts considered as "tender" $(3.2<\mathrm{WBSF}<3.9 \mathrm{~kg})$ were the loin, strip-loin, shoulderchuck-roll and shoulder-clod; the cuts considered as "intermediate" $(3.9<\mathrm{WBSF}<4.6 \mathrm{~kg})$ were the top-round, brisket, outside-round and brisket and short-plate-brisket; and the cut considered as "tough" (WBSF $>4.6 \mathrm{~kg}$ ) was the shank. Moreover, the WBSF values of cuts in the present study were almost equal the values (3.49 to $4.57 \mathrm{~kg}$ ) reported for the longissimus dorsi, semimembranosus, semitendinosus, triceps brachii, psoas major, and biceps femoris muscles of horses slaughtered at 15-mo-old (Lorenzo et al., 2013; Franco and Lorenzo, 2014), but lower than the values $(5.24$ to $5.95 \mathrm{~kg})$ reported by Tateo et al. (2008) for the various muscles of 11-mo-old foals. The differences in the WBSF values for the muscles examined between the studies could be due to the effects by factors related to the breed, feeding condition, and post-slaughter treatment etc.

\section{Effect of cut type on fatty acid composition}

The relative percentage of intramuscular fatty acid composition in different cuts is presented in Table 4. The outcome of our analysis revealed that significant differences in levels of all fatty acids occurred between the cuts with exception of oleic acid (C18:1n-9), linolenic acid (C18:3n3), eicosenoic acid (C20:1n9) and arachidonic acid (C22:4n6). It was also observed that four the most abundant fatty acids detected in all cuts were palmitic acid (C16:0), oleic acid (C18:1n-9), linoleic acid (C18:2n-6) and linolenic acid (C18:3n3). In particular, the levels of C16:0 in loin (31.16\%) and strip-loin $(31.02 \%)$ were significantly $(\mathrm{p}<0.05)$ higher than those in top-round (28.45\%) and shank (28.13\%) but similar to those of other remaining cuts. Similarly, the tender-loin and top-round had higher levels of C18:2n-6 than short-plate-brisket $(\mathrm{p}<0.05)$. The SFA, unsaturated fatty acids (UFA), PUFA contents also showed significant differences with their levels ranging between the cuts from $36.31 \%$ to $39.57 \%, 60.43 \%$ to $63.69 \%$, and $20.15 \%$ to $24.80 \%$, respectively. The differences in fatty acid composition could be due to the differences in triglycerides and phospholipids contents between the cuts. Our finding agrees well with those of Tateo et al. (2008), Lorenzo and Pateiro (2013), and Franco and Lorenzo (2014), who showed a significant effect of type of muscle on fatty acid composition of foal meat. Compared with our data, those of Tateo et al. (2008) found higher SFA (43.69\% to $45.22 \%$ ) and similar PUFA $(21.37 \%$ to $24.75 \%$ ) contents in different muscles of 11-mo-old foals. In addition, higher SFA (44.49\% to $45.38 \%$ ) and lower MUFA (28.90\%) were detected in longissimus dorsi muscle of foals slaughtered at 6-18-mo-old (Palo et al., 2013). In contrast, lower SFA (33.62\% to $36.08 \%)$ and higher PUFA (23.23\% to $38.93 \%)$ contents were detected in various muscles of foals slaughtered at 15-mo-old (Franco and Lorenzo, 2014). These contrasting results are probably due to the breed, age and feeding diet differences between the studies.

Dietary n-3 PUFA have long been known to have effects on physiological processes, (Jump, 2002) therefore there

Table 4. Relative percentage of fatty acids (mean \pm standard error) of horse meat as affected by cut type

\begin{tabular}{|c|c|c|c|c|c|c|c|c|c|c|}
\hline Cut type & Tender-loin & Loin & Strip-loin & $\begin{array}{l}\text { Shoulder- } \\
\text { chuck-roll }\end{array}$ & Shoulder-clod & Top-round & $\begin{array}{c}\text { Outside- } \\
\text { round }\end{array}$ & Brisket & $\begin{array}{c}\text { Short-plate- } \\
\text { brisket }\end{array}$ & Shank \\
\hline$\overline{\mathrm{C} 14: 0}$ & $4.57 \pm 0.44^{\mathrm{a}}$ & $4.47 \pm 0.14^{\mathrm{ab}}$ & $4.38 \pm 0.29^{\mathrm{ab}}$ & $4.21 \pm 0.23^{\mathrm{abc}}$ & $4.46 \pm 0.17^{\mathrm{ab}}$ & $4.00 \pm 0.22^{\mathrm{c}}$ & $4.28 \pm 0.28^{\mathrm{abc}}$ & $4.18 \pm 0.16^{\mathrm{bc}}$ & $4.45 \pm 0.15^{\mathrm{ab}}$ & $3.99 \pm 0.24^{\mathrm{c}}$ \\
\hline C16:0 & $30.08 \pm 1.66^{\mathrm{abc}}$ & $31.16 \pm 1.52^{\mathrm{a}}$ & $31.02 \pm 1.44^{\mathrm{a}}$ & $29.79 \pm 0.93^{\mathrm{abc}}$ & $29.79 \pm 0.63^{\mathrm{abc}}$ & $28.45 \pm 1.43^{\mathrm{bc}}$ & $30.36 \pm 2.83^{\mathrm{abc}}$ & $28.83 \pm 1.47^{\mathrm{abc}}$ & $30.49 \pm 1.16^{\mathrm{ab}}$ & $28.13 \pm 1.26^{\mathrm{c}}$ \\
\hline $\mathrm{C} 16: \ln 7$ & $5.10 \pm 1.02^{\mathrm{b}}$ & $6.31 \pm 1.42^{\mathrm{ab}}$ & $.6 \pm 1.03^{\mathrm{ab}}$ & $6.55 \pm 1.28^{\mathrm{ab}}$ & $6.18 \pm 0.53^{\mathrm{ab}}$ & $5.71 \pm 0.96^{\mathrm{ab}}$ & $6.42 \pm 1.27^{\mathrm{ab}}$ & $6.27 \pm 1.50^{\mathrm{ab}}$ & $6.95 \pm 1.07^{\mathrm{a}}$ & $5.88 \pm 0.73^{\mathrm{ab}}$ \\
\hline C18:0 & $4.74 \pm 0.51^{\mathrm{a}}$ & $3.87 \pm 0.36^{\mathrm{b}}$ & $4.16 \pm 0.40^{\mathrm{ab}}$ & $3.56 \pm 0.29^{b}$ & $3.91 \pm 0.47^{\mathrm{b}}$ & $4.28 \pm 0.80^{\mathrm{ab}}$ & $4.18 \pm 0.56^{\mathrm{ab}}$ & $3.79 \pm 0.35^{\mathrm{b}}$ & $3.87 \pm 0.15^{\mathrm{b}}$ & $4.19 \pm 0.61^{\mathrm{ab}}$ \\
\hline C18:1n9 & $30.82 \pm 1.37$ & $32.78 \pm 1.90$ & $31.96 \pm 1.98$ & $34.52 \pm 2.63$ & $32.44 \pm 2.71$ & $32.31 \pm 2.87$ & $32.03 \pm 3.71$ & $33.98 \pm 1.25$ & $33.58 \pm 2.48$ & $33.92 \pm 2.97$ \\
\hline C18:1n7 & $0.03 \pm 0.00^{\mathrm{b}}$ & $0.04 \pm 0.01^{\mathrm{ab}}$ & $.04 \pm 0.01^{\mathrm{ab}}$ & $0.05 \pm 0.03^{\mathrm{a}}$ & $0.03 \pm 0.01^{\mathrm{ab}}$ & $0.03 \pm 0.01^{\mathrm{ab}}$ & $0.04 \pm 0.00^{\mathrm{ab}}$ & $0.03 \pm 0.01^{\mathrm{ab}}$ & $0.04 \pm 0.01^{\mathrm{ab}}$ & $0.03 \pm 0.01^{\mathrm{b}}$ \\
\hline C18:2n6 & $19.38 \pm 1.86^{\mathrm{a}}$ & $16.42 \pm 1.52^{\mathrm{ab}}$ & $16.64 \pm 1.96^{\mathrm{ab}}$ & $16.33 \pm 2.16^{\mathrm{ab}}$ & $17.82 \pm 2.15^{\mathrm{ab}}$ & $19.42 \pm 3.60^{\mathrm{a}}$ & $17.42 \pm 1.68^{\mathrm{ab}}$ & $17.60 \pm 1.41^{\mathrm{ab}}$ & $15.84 \pm 1.42^{\mathrm{b}}$ & $17.88 \pm 2.07^{\mathrm{ab}}$ \\
\hline C18:3n6 & $0.02 \pm 0.00^{\mathrm{abc}}$ & $0.02 \pm 0.01^{\mathrm{bc}}$ & $0.02 \pm 0.01^{\mathrm{abc}}$ & $0.02 \pm 0.00^{\mathrm{abc}}$ & $0.02 \pm 0.00^{\mathrm{abc}}$ & $0.03 \pm 0.01^{\mathrm{ab}}$ & $0.02 \pm 0.00^{\mathrm{abc}}$ & $0.02 \pm 0.00^{\mathrm{abc}}$ & $0.02 \pm 0.01^{\mathrm{c}}$ & $0.03 \pm 0.01^{\mathrm{a}}$ \\
\hline C18:3n3 & $4.54 \pm 1.46$ & $4.28 \pm 0.78$ & $4.49 \pm 0.41$ & $4.29 \pm 0.74$ & $4.71 \pm 0.55$ & $4.71 \pm 0.73$ & $4.45 \pm 0.47$ & $4.59 \pm 0.54$ & $4.12 \pm 0.80$ & $4.89 \pm 0.47$ \\
\hline $\mathrm{C} 20: \ln 9$ & $0.42 \pm 0.06$ & $0.47 \pm 0.07$ & $0.47 \pm 0.03$ & $0.42 \pm 0.10$ & $0.47 \pm 0.05$ & $0.41 \pm 0.07$ & $0.48 \pm 0.02$ & $0.46 \pm 0.07$ & $0.48 \pm 0.08$ & $0.46 \pm 0.04$ \\
\hline C20:4n6 & $0.23 \pm 0.07^{\mathrm{ab}}$ & $0.15 \pm 0.04^{b}$ & $0.19 \pm 0.06^{\mathrm{ab}}$ & $0.22 \pm 0.07^{\mathrm{ab}}$ & $0.14 \pm 0.03^{b}$ & $0.57 \pm 0.69^{\mathrm{a}}$ & $0.27 \pm 0.12^{\mathrm{ab}}$ & $0.22 \pm 0.05^{\mathrm{ab}}$ & $0.13 \pm 0.03^{b}$ & $0.51 \pm 0.39^{\mathrm{ab}}$ \\
\hline $\mathrm{C} 20: 5 \mathrm{n} 3$ & $0.01 \pm 0.00^{\mathrm{b}}$ & $0.01 \pm 0.00^{\mathrm{ab}}$ & $0.01 \pm 0.00^{\mathrm{ab}}$ & $0.01 \pm 0.00^{\mathrm{ab}}$ & $0.01 \pm 0.00^{\mathrm{ab}}$ & $0.02 \pm 0.01^{\mathrm{a}}$ & $0.01 \pm 0.00^{\mathrm{ab}}$ & $0.01 \pm 0.00^{\mathrm{ab}}$ & $0.01 \pm 0.00^{\mathrm{ab}}$ & $0.02 \pm 0.01^{\mathrm{a}}$ \\
\hline $\mathrm{C} 22: 4 \mathrm{n} 6$ & $0.04 \pm 0.01$ & $0.03 \pm 0.01$ & $0.03 \pm 0.01$ & $0.04 \pm 0.01$ & $0.03 \pm 0.01$ & $0.06 \pm 0.05$ & $0.04 \pm 0.02$ & $0.03 \pm 0.01$ & $0.03 \pm 0.01$ & $0.05 \pm 0.02$ \\
\hline SFA & $39.39 \pm 2.08^{\mathrm{abc}}$ & $39.51 \pm 1.62^{\mathrm{ab}}$ & $39.57 \pm 1.69^{\mathrm{a}}$ & $37.57 \pm 1.19^{\mathrm{abcd}}$ & $38.15 \pm 1.13^{\mathrm{abcd}}$ & $36.73 \pm 1.64^{\mathrm{cd}}$ & $38.81 \pm 3.32^{\mathrm{abcd}}$ & $36.80 \pm 1.63^{\mathrm{bcd}}$ & $38.81 \pm 1.21^{\mathrm{abcd}}$ & $36.31 \pm 1.54^{\mathrm{d}}$ \\
\hline UFA & $60.61 \pm 2.08^{\mathrm{bcd}}$ & $60.50 \pm 1.62^{\text {cd }}$ & $60.43 \pm 1.69^{d}$ & $62.43 \pm 1.19^{\mathrm{abcd}}$ & $61.85 \pm 1.13^{\mathrm{abcd}}$ & $63.27 \pm 1.64^{\mathrm{ab}}$ & $61.19 \pm 3.32^{\mathrm{abcd}}$ & $63.20 \pm 1.63^{\mathrm{abc}}$ & $61.19 \pm 1.21^{\mathrm{abcd}}$ & $63.69 \pm 1.54^{\mathrm{a}}$ \\
\hline MUFA & $36.38 \pm 1.93^{b}$ & $39.60 \pm 0.60^{\mathrm{ab}}$ & $39.06 \pm 2.31^{\mathrm{ab}}$ & $41.53 \pm 3.06^{\mathrm{a}}$ & $39.12 \pm 3.13^{\mathrm{ab}}$ & $38.47 \pm 3.65^{\mathrm{ab}}$ & $38.97 \pm 2.96^{\mathrm{ab}}$ & $40.74 \pm 0.64^{\mathrm{a}}$ & $41.05 \pm 1.87^{\mathrm{a}}$ & $40.31 \pm 3.25^{\mathrm{a}}$ \\
\hline PUFA & $24.23 \pm 2.75^{\mathrm{ab}}$ & $20.90 \pm 1.63^{\mathrm{bc}}$ & $21.37 \pm 2.18^{\mathrm{abc}}$ & $20.91 \pm 2.73^{\mathrm{bc}}$ & $22.73 \pm 2.53^{\mathrm{abc}}$ & $24.80 \pm 3.70^{\mathrm{a}}$ & $22.22 \pm 1.58^{\mathrm{abc}}$ & $22.46 \pm 1.57^{\mathrm{abc}}$ & $20.15 \pm 1.91^{\mathrm{c}}$ & $23.39 \pm 2.41^{\mathrm{abc}}$ \\
\hline n3 & $4.56 \pm 1.46$ & $4.29 \pm 0.78$ & $4.50 \pm 0.40$ & $4.30 \pm 0.74$ & $4.72 \pm 0.55$ & $4.73 \pm 0.71$ & $4.46 \pm 0.48$ & $4.60 \pm 0.54$ & $4.13 \pm 0.80$ & $4.91 \pm 0.47$ \\
\hline n6 & $19.68 \pm 1.93^{\mathrm{a}}$ & $16.62 \pm 1.55^{\mathrm{ab}}$ & $16.87 \pm 2.00^{\mathrm{ab}}$ & $16.60 \pm 2.21^{\mathrm{ab}}$ & $18.01 \pm 2.18^{\mathrm{ab}}$ & $20.08 \pm 4.35^{\mathrm{a}}$ & $17.75 \pm 1.81^{\mathrm{ab}}$ & $17.87 \pm 1.45^{\mathrm{ab}}$ & $16.02 \pm 1.45^{\mathrm{b}}$ & $18.47 \pm 2.48^{\mathrm{ab}}$ \\
\hline $\mathrm{n} 6 / \mathrm{n} 3$ & $4.88 \pm 2.27^{\mathrm{b}}$ & $3.99 \pm 0.97^{\mathrm{ab}}$ & $3.76 \pm 0.43^{\mathrm{ab}}$ & $3.91 \pm 0.55^{\mathrm{a}}$ & $3.83 \pm 0.41^{\mathrm{ab}}$ & $4.48 \pm 1.95^{\mathrm{ab}}$ & $4.04 \pm 0.83^{\mathrm{ab}}$ & $3.93 \pm 0.56^{\mathrm{a}}$ & $3.98 \pm 0.76^{\mathrm{ab}}$ & $3.80 \pm 0.74^{\mathrm{a}}$ \\
\hline MUFA/SFA & $0.93 \pm 0.07^{\mathrm{abc}}$ & $1.01 \pm 0.04^{\mathrm{bc}}$ & $0.99 \pm 0.09^{\mathrm{bc}}$ & $1.11 \pm 0.10^{\mathrm{bc}}$ & $1.03 \pm 0.11^{\mathrm{abc}}$ & $1.05 \pm 0.12^{\mathrm{a}}$ & $1.01 \pm 0.15 \mathrm{a}^{\mathrm{bc}}$ & $1.11 \pm 0.06^{\mathrm{abc}}$ & $1.06 \pm 0.07^{\mathrm{c}}$ & $1.11 \pm 0.13^{\mathrm{ab}}$ \\
\hline PUFA/SFA & $0.62 \pm 0.09$ & $0.53 \pm 0.06$ & $0.54 \pm 0.06$ & $0.56 \pm 0.07$ & $0.60 \pm 0.06$ & $0.68 \pm 0.11$ & $0.58 \pm 0.07$ & $0.61 \pm 0.07$ & $0.52 \pm 0.06$ & $0.65 \pm 0.06$ \\
\hline
\end{tabular}

SFA, saturated fatty acid; UFA, unsaturated fatty acid; MUFA, monounsaturated fatty acid; PUFA, polyunsaturated fatty acid.

${ }^{a-f}$ Means with different superscripts in the same row differ significantly $(p<0.05)$ 
has been much interest in the beneficial effects of these n3PUFAs especially C18:3n-3 and eicosapentaenoic acid (C20:5n3) (Burdge and Calder, 2005). Our results showed that the $n-3$ content was similar for all cuts examined. Also, the recommendations for the PUFA/SFA ratio for a healthy diet as a whole should be 0.40 or higher, while the ratio of $n-6 / n-3$ fatty acids should be 4.0 or lower (Department of Health, 1994) because the ratio between $n-6$ and $n-3$ fatty acids plays an important role in reducing the risk of coronary heart disease (American Heart Association, 2008). According to the outcome of our analysis, the PUFA/SFA ratios in all of cuts examined were above the recommended value of 0.4 . Additionally, the $n-6 / n-3$ ratios in all cuts were also within the recommended values of less than 4.0 with exceptions of few cuts such as tender-loin and top-round. Similar to our results, previous studies on horse meat slaughtered at different ages also showed the favorable PUFA/SFA and $n-6 / n-3$ ratios (Sarriés and Beriain, 2005; Tateo et al., 2008; Lorenzo and Pateiro, 2013; Palo et al., 2013; Franco and Lorenzo, 2014). However, some authors have reported an unfavorable $n-6 / n-3$ ratio (above the recommended values of less than 4.0) in longissimus dorsi muscle of foals slaughtered at 11-, 16- and 24-mo-old (Sarriés et al., 2006). In general, the horse meat cuts in the present study as well as in previous studies as cited above showed healthier fatty acid profile, characterized by lower SFA, higher PUFA contents, and more favorable PUFA/SFA and $n-6 / n-3$ ratios in comparison with those in conventional meats such as beef (Ba et al., 2013).

\section{Effect of cut type on mineral composition}

The mineral contents significantly $(\mathrm{p}<0.05)$ differed between the cuts (Table 5). Among the macro-elements detected, the concentrations of potassium (K) were generally higher than others, followed by phosphorous (P) (in decreasing order), sodium $(\mathrm{Na})$, magnesium $(\mathrm{Mg})$ and calcium (Ca). The $\mathrm{Na}, \mathrm{P}, \mathrm{Ca}, \mathrm{K}$ and $\mathrm{Mg}$ contents ranged between the cuts from $489 \mathrm{mg} / \mathrm{kg}$ to $799.14 \mathrm{mg} / \mathrm{kg}$, $2,415.45 \mathrm{mg} / \mathrm{kg}$ to $2,740.96 \mathrm{mg} / \mathrm{kg}, 55.20 \mathrm{mg} / \mathrm{kg}$ to 69.85 $\mathrm{mg} / \mathrm{kg}, 2,680.40 \mathrm{mg} / \mathrm{kg}$ to $3,463.31 \mathrm{mg} / \mathrm{kg}$, and 199.12 $\mathrm{mg} / \mathrm{kg}$ to $254.63 \mathrm{mg} / \mathrm{kg}$, respectively. Compared to various muscles of foals slaughtered at 15-mo-old (Lorenzo and
Pateiro, 2013; Franco and Lorenzo, 2014), the cuts in the present study had higher $\mathrm{P}, \mathrm{Ca}$, and $\mathrm{K}$ contents but had similar $\mathrm{Na}$ and lower $\mathrm{Mg}$ contents.

Among the minerals often found in foods, iron $(\mathrm{Fe})$, manganese $(\mathrm{Mn})$ and copper $(\mathrm{Cu})$ are grouped as trace elements that are vital for maintaining human health, insufficient intake of these trace minerals can cause symptoms of nutritional deficiency (Tapiero and Tew, 2003). The outcome of our analysis showed that the highest $\mathrm{Cu}$ content was found in shoulder-clod $(2.75 \mathrm{mg} / \mathrm{kg})$, lower in brisket $(2.37 \mathrm{mg} / \mathrm{kg})$ and lowest in strip-loin $(1.52 \mathrm{mg} / \mathrm{kg})$ $(\mathrm{p}<0.05)$. Regarding Fe content, its concentrations ranged between the cuts from $21.25 \mathrm{mg} / \mathrm{kg}$ to $30.85 \mathrm{mg} / \mathrm{kg}$ in which the cuts that had the highest Fe contents were tenderloin and shoulder-chuck-roll whereas short-plate-brisket had the lowest Fe content. For the $\mathrm{Zn}$ content, the highest concentration was found in shoulder-chuck-roll (54.49 $\mathrm{mg} / \mathrm{kg})$, lower in shank $(40.42 \mathrm{mg} / \mathrm{kg})$, followed by loin $(34.75 \mathrm{mg} / \mathrm{kg})$, top-round $(25.54 \mathrm{mg} / \mathrm{kg})$ and tender-loin $(25.40 \mathrm{mg} / \mathrm{kg})$, whereas the lowest in strip-loin $(16.51$ $\mathrm{mg} / \mathrm{kg})(\mathrm{p}<0.05)$. The concentrations of $\mathrm{Cu}$ and $\mathrm{Zn}$ in most of cuts in our study were slightly higher than the values reported for various muscles of foals slaughtered at 15-moold in literature (Lorenzo and Pateiro, 2013). In addition, similar $\mathrm{Cu}, \mathrm{Fe}$ and $\mathrm{Zn}$ contents have been reported by Franco and Lorenzo (2014) for various muscles of 15-moold foals. On the other hand, when compared to the Fe contents in other meat types such as, beef muscles (19.3 to $20.07 \mathrm{mg} / \mathrm{kg})$, pork loin $(3.60 \mathrm{mg} / \mathrm{kg})$ and chicken breast (4 $\mathrm{mg} / \mathrm{kg}$ ) reported in literature (Ramos et al., 2009), all of cuts studied had higher Fe contents.

\section{Effect of cut type on amino acid composition}

The amino acid (AA) contents of horse meat cuts are shown in Table 6. Our results depict that sixteen amino acids including essential amino acids (EAA) and nonessential amino acids (NAA) were found, and their amounts significantly differed among the cuts. EAA cannot be produced by the human body, thus they must be supplied by diet. Without these EAA, the body is unable to function normally, and also the presence of amino acids enables vitamins and minerals to perform all their physiological

Table 5. Mineral contents (mean \pm standard error) of horse meat as affected by cut type

\begin{tabular}{|c|c|c|c|c|c|c|c|c|c|c|}
\hline Cut type & Tender-loin & Loin & Strip-loin & $\begin{array}{l}\text { Shoulder- } \\
\text { chuck-roll }\end{array}$ & Shoulder-clod & Top-round & $\begin{array}{l}\text { Outside- } \\
\text { round }\end{array}$ & Brisket & $\begin{array}{c}\text { Short-plate- } \\
\text { brisket }\end{array}$ & Shank \\
\hline \multicolumn{11}{|c|}{ Macro-elements } \\
\hline $\mathrm{Na}(\mathrm{mg} / \mathrm{kg})$ & $555.27 \pm 66^{\mathrm{dc}}$ & $523.13 \pm 49.6^{\mathrm{dc}}$ & $489.00 \pm 35.99^{\mathrm{d}}$ & $659.74 \pm 66.40^{\mathrm{b}}$ & $585.60 \pm 61^{\mathrm{bc}}$ & $571.69 \pm 55.32^{\mathrm{dc}}$ & $552.64 \pm 47.42^{\mathrm{dc}}$ & $569.59 \pm 58.58^{\mathrm{dc}}$ & $654.36 \pm 87.76^{\mathrm{b}}$ & $799.14 \pm 54^{\mathrm{a}}$ \\
\hline $\mathrm{P}(\mathrm{mg} / \mathrm{kg})$ & $2,740.96 \pm 187^{\mathrm{a}}$ & $2,405.09 \pm 82^{\mathrm{de}}$ & $2,609.04 \pm 70^{\mathrm{abc}}$ & $2,366.31 \pm 52^{\mathrm{de}}$ & $2,464.76 \pm 41^{\mathrm{dc}}$ & $2,677.06 \pm 61^{\mathrm{ab}}$ & $2,586.71 \pm 75.8^{\mathrm{bc}}$ & $2,512.15 \pm 134^{\mathrm{dc}}$ & $2,265.85 \pm 122^{\mathrm{e}}$ & $2,415.45 \pm 68^{d}$ \\
\hline $\mathrm{Ca}(\mathrm{mg} / \mathrm{kg})$ & $58.55 \pm 6.92^{\mathrm{bc}}$ & $59.18 \pm 10.05^{\mathrm{bc}}$ & $59.49 \pm 9.71^{\mathrm{bc}}$ & $62.38 \pm 9.38^{\mathrm{bc}}$ & $69.85 \pm 12.09^{\mathrm{a}}$ & $55.53 \pm 9.90^{\mathrm{c}}$ & $55.20 \pm 6.11^{\mathrm{c}}$ & $58.36 \pm 7.25^{\mathrm{bc}}$ & $66.66 \pm 10.05^{\mathrm{ab}}$ & $57.27 \pm 2.04^{\mathrm{bc}}$ \\
\hline $\mathrm{K}(\mathrm{mg} / \mathrm{kg})$ & $3,378.24 \pm 143^{\mathrm{ab}}$ & $3,034.43 \pm 10^{\mathrm{d}}$ & $3,463.31 \pm 111^{\mathrm{a}}$ & $2,950.68 \pm 130^{\mathrm{ed}}$ & $3,080.73 \pm 89^{\mathrm{cd}}$ & $3,242.82 \pm 107^{\mathrm{cb}}$ & $3,214.21 \pm 139^{\mathrm{cb}}$ & $3,108.55 \pm 190^{\mathrm{cd}}$ & $2,807.50 \pm 119^{\text {ef }}$ & $2,680.40 \pm 43^{\mathrm{f}}$ \\
\hline $\mathrm{Mg}(\mathrm{mg} / \mathrm{kg})$ & $247.36 \pm 5.4^{\mathrm{ab}}$ & $216.20 \pm 12.6^{\mathrm{d}}$ & $254.63 \pm 9.01^{\mathrm{a}}$ & $199.12 \pm 5.51^{\mathrm{e}}$ & $230.62 \pm 2.79^{\mathrm{c}}$ & $251.23 \pm 9.85^{\mathrm{a}}$ & $242.19 \pm 11^{\mathrm{abc}}$ & $234.16 \pm 13.64^{\mathrm{bc}}$ & $210.76 \pm 12.90^{\mathrm{de}}$ & $213.99 \pm 5.70^{\mathrm{d}}$ \\
\hline \multicolumn{11}{|l|}{ Trace-elements } \\
\hline $\mathrm{Cu}(\mathrm{mg} / \mathrm{kg})$ & $2.11 \pm 0.64^{\mathrm{cb}}$ & $1.72 \pm 0.60^{\mathrm{cd}}$ & $1.52 \pm 0.16^{\mathrm{d}}$ & $1.85 \pm 0.34^{\mathrm{cbd}}$ & $2.75 \pm 0.66^{\mathrm{a}}$ & $1.67 \pm 0.31^{\mathrm{cd}}$ & $2.07 \pm 0.21^{\mathrm{cb}}$ & $2.37 \pm 0.68^{\mathrm{b}}$ & $1.82 \pm 0.30^{\mathrm{cbd}}$ & $2.00 \pm 0.32^{\mathrm{cbd}}$ \\
\hline $\mathrm{Fe}(\mathrm{mg} / \mathrm{kg})$ & $30.85 \pm 7.74^{\mathrm{a}}$ & $25.40 \pm 3.54^{\mathrm{b}}$ & $24.89 \pm 5.18^{\mathrm{bc}}$ & $30.42 \pm 3.23^{\mathrm{a}}$ & $28.06 \pm 3.08^{\mathrm{ab}}$ & $25.97 \pm 4.03^{\mathrm{b}}$ & $28.35 \pm 4.60^{\mathrm{ab}}$ & $28.20 \pm 4.93^{\mathrm{ab}}$ & $21.25 \pm 2.50^{\mathrm{c}}$ & $25.01 \pm 2.63^{\mathrm{bc}}$ \\
\hline $\mathrm{Zn}(\mathrm{mg} / \mathrm{kg})$ & $25.40 \pm 5.27^{\mathrm{e}}$ & $34.75 \pm 1.89^{c}$ & $16.51 \pm 2.29^{\mathrm{f}}$ & $54.49 \pm 4.51^{\mathrm{a}}$ & $29.16 \pm 4.38^{\mathrm{ed}}$ & $25.54 \pm 3.99^{\mathrm{e}}$ & $27.64 \pm 3.37^{\mathrm{ed}}$ & $27.59 \pm 2.20^{\text {ed }}$ & $27.03 \pm 3.34^{\mathrm{ed}}$ & $40.42 \pm 3.84^{\mathrm{b}}$ \\
\hline
\end{tabular}

${ }^{a-f}$ Means with different superscripts in the same row differ significantly $(p<0.05)$. 
Table 6. Amino acid contents (mean \pm standard error, $\mathrm{g} / 100 \mathrm{~g}$ ) of horse meat as affected by cut type

\begin{tabular}{|c|c|c|c|c|c|c|c|c|c|c|}
\hline Cut type & Tender-loin & Loin & Strip-loin & $\begin{array}{l}\text { Shoulder- } \\
\text { chuck -roll }\end{array}$ & Shoulder-clod & Top-round & $\begin{array}{l}\text { Outside- } \\
\text { round }\end{array}$ & Brisket & $\begin{array}{c}\text { Short-plate- } \\
\text { brisket }\end{array}$ & Shank \\
\hline \multicolumn{11}{|c|}{ Essential amino acids (EA) } \\
\hline HIS & $0.86 \pm 0.02^{\mathrm{de}}$ & $0.85 \pm 0.03^{\mathrm{de}}$ & $1.04 \pm 0.07^{\mathrm{a}}$ & $0.71 \pm 0.01^{\mathrm{g}}$ & $83 \pm 0.02^{\mathrm{def}}$ & $0.97 \pm 0.03^{b}$ & $0.91 \pm 0.02^{\mathrm{c}}$ & $.88 \pm 0.06^{\mathrm{cd}}$ & $0.79 \pm 0.04^{\mathrm{f}}$ & $0.81 \pm 0.03^{\text {ef }}$ \\
\hline 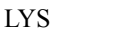 & $81 \pm 0.02^{\mathrm{abc}}$ & $78 \pm 0.09^{\mathrm{bc}}$ & $84 \pm 0.17^{\mathrm{ab}}$ & $1.78 \pm 0.06^{\mathrm{bc}}$ & $.70 \pm 0.03^{\mathrm{cd}}$ & $1.92 \pm 0.05^{\mathrm{a}}$ & $1.81 \pm 0.07^{\mathrm{abc}}$ & $1.76 \pm 0.05^{\mathrm{bc}}$ & $1.61 \pm 0.10^{\mathrm{d}}$ & $1.85 \pm 0.09^{\mathrm{ab}}$ \\
\hline MET & $0.54 \pm 0.00^{\mathrm{a}}$ & $0.51 \pm 0.03^{\mathrm{ab}}$ & $0.52 \pm 0.01^{\mathrm{ab}}$ & $0.47 \pm 0.02^{\mathrm{cd}}$ & $0.49 \pm 0.01^{\text {bcd }}$ & $0.52 \pm 0.05^{\mathrm{ab}}$ & $0.51 \pm 0.01^{\mathrm{ab}}$ & $0.49 \pm 0.02^{\text {bcd }}$ & $0.46 \pm 0.02^{\mathrm{d}}$ & $0.50 \pm 0.03^{b c}$ \\
\hline LEU & $73 \pm 0.02^{\mathrm{bc}}$ & $1.69 \pm 0.10^{\mathrm{bc}}$ & $1.76 \pm 0.16^{\mathrm{ab}}$ & $1.70 \pm 0.04^{\mathrm{bc}}$ & $1.63 \pm 0.03^{\mathrm{cd}}$ & $1.85 \pm 0.05^{\mathrm{a}}$ & $1.73 \pm 0.06^{\mathrm{bc}}$ & $1.68 \pm 0.06^{\mathrm{bc}}$ & $1.53 \pm 0.09^{\mathrm{d}}$ & $1.76 \pm 0.08^{\mathrm{ab}}$ \\
\hline THR & & $0.92 \pm 0.05^{\mathrm{bc}}$ & $0.96 \pm$ & $0.92 \pm 0.03^{\mathrm{bc}}$ & & $1.00 \pm 0.02^{\mathrm{a}}$ & $0.94 \pm 0.03^{b}$ & $0.91 \pm 0.03^{\mathrm{bc}}$ & $0.84 \pm 0.04^{\mathrm{d}}$ & $0.96 \pm 0.04^{\mathrm{ab}}$ \\
\hline & $4 \pm 0.01^{\mathrm{bcd}}$ & $0.84 \pm 0.05^{\text {bcd }}$ & $0.89 \pm 0.08^{\mathrm{ab}}$ & $0.82 \pm 0.02^{\text {cde }}$ & $0.79 \pm 0.01^{\mathrm{de}}$ & $0.93 \pm 0.03^{\mathrm{a}}$ & $0.86 \pm 0.03^{\mathrm{bc}}$ & $0.82 \pm 0.02^{\text {cde }}$ & $0.77 \pm 0.05^{\mathrm{e}}$ & $0.88 \pm 0.04^{\mathrm{abc}}$ \\
\hline VAL & $0.89 \pm 0.01^{\text {bcde }}$ & $0.91 \pm 0.06^{\text {bcd }}$ & $0.94 \pm 0.08^{\mathrm{abc}}$ & $0.90 \pm 0.02^{\text {bcde }}$ & $0.86 \pm 0.01^{\mathrm{de}}$ & $0.99 \pm 0.03^{\mathrm{a}}$ & $0.91 \pm 0.03^{\mathrm{bcd}}$ & $0.89 \pm 0.02^{\text {cde }}$ & $0.84 \pm 0.05^{\mathrm{ef}}$ & $0.95 \pm 0.04^{\mathrm{ab}}$ \\
\hline PHE & $4 \pm 0.01^{\mathrm{bc}}$ & $0.82 \pm 0.04^{\mathrm{bc}}$ & $0.86 \pm 0.07^{\mathrm{ab}}$ & $0.83 \pm 0.03^{\mathrm{bc}}$ & $0.80 \pm 0.01^{\mathrm{cd}}$ & & $0.84 \pm 0.02^{\mathrm{bc}}$ & & $0.76 \pm 0.04^{\mathrm{d}}$ & $0.90 \pm 0.03^{\mathrm{a}}$ \\
\hline$\Sigma$ EA & $8.45 \pm 0.01^{\mathrm{bc}}$ & $8.32 \pm 0.04^{\mathrm{bc}}$ & $8.81 \pm 0.15^{\text {ab }}$ & $6.35 \pm 0.03^{\mathrm{d}}$ & $7.98 \pm 0.02^{\mathrm{c}}$ & $9.07 \pm 0.04^{\mathrm{a}}$ & $8.51 \pm 0.04^{\mathrm{b}}$ & $8.26 \pm 0.03^{\mathrm{cd}}$ & $7.60 \pm 0.05^{\mathrm{cd}}$ & $8.61 \pm 0.04^{\mathrm{ab}}$ \\
\hline \multicolumn{11}{|c|}{ Non-essential amino acid (NAA) } \\
\hline ALA & $1.20 \pm 0.02^{\mathrm{cd}}$ & $1.24 \pm 0.08^{\mathrm{c}}$ & $1.22 \pm 0.10^{\mathrm{c}}$ & $1.25 \pm 0.03^{\mathrm{bc}}$ & $1.20 \pm 0.03^{\mathrm{cd}}$ & $1.32 \pm 0.05^{\mathrm{ab}}$ & $1.22 \pm 0.03^{\mathrm{c}}$ & $1.23 \pm 0.05^{\mathrm{c}}$ & $1.13 \pm 0.06^{\mathrm{de}}$ & $1.37 \pm 0.08^{\mathrm{a}}$ \\
\hline GLY & $0.90 \pm 0.03^{\mathrm{c}}$ & $1.03 \pm 0.08^{\mathrm{b}}$ & $0.96 \pm 0.05^{\mathrm{bc}}$ & $1.03 \pm 0.03^{\mathrm{b}}$ & $1.05 \pm 0.07^{\mathrm{b}}$ & $1.03 \pm 0.10^{\mathrm{b}}$ & $0.97 \pm 0.03^{\mathrm{bc}}$ & $1.07 \pm 0.08^{b}$ & $0.98 \pm 0.05^{\mathrm{bc}}$ & $1.31 \pm 0.20^{\mathrm{a}}$ \\
\hline GLU & $2.98 \pm 0.02^{\mathrm{cd}}$ & $2.92 \pm 0.14^{\mathrm{cd}}$ & $3.05 \pm 0.26^{\mathrm{abc}}$ & $3.00 \pm 0.09^{\mathrm{bcd}}$ & $2.84 \pm 0.06^{\mathrm{de}}$ & $3.19 \pm 0.08^{\mathrm{a}}$ & $3.02 \pm 0.12^{\mathrm{abcd}}$ & $2.90 \pm 0.11^{\mathrm{cd}}$ & $2.72 \pm 0.15^{\mathrm{e}}$ & $3.18 \pm 0.12^{\mathrm{ab}}$ \\
\hline TYR & $0.67 \pm 0.01^{\mathrm{abc}}$ & $0.66 \pm 0.04^{\mathrm{abc}}$ & $0.67 \pm 0.07^{\mathrm{abc}}$ & $0.68 \pm 0.02^{\mathrm{a}}$ & $0.62 \pm 0.01^{\mathrm{c}}$ & $0.71 \pm 0.02^{\mathrm{a}}$ & $0.68 \pm 0.05^{\mathrm{ab}}$ & $0.63 \pm 0.02^{\mathrm{bc}}$ & $0.62 \pm 0.05^{\mathrm{c}}$ & $0.71 \pm 0.05^{\mathrm{a}}$ \\
\hline ASP & $1.90 \pm 0.01^{\mathrm{bc}}$ & $1.85 \pm 0.09^{\mathrm{bcd}}$ & $1.95 \pm 0.16^{\mathrm{ab}}$ & $1.83 \pm 0.05^{\mathrm{cd}}$ & & $2.01 \pm 0.05^{\mathrm{a}}$ & $1.89 \pm 0.07^{\mathrm{bc}}$ & & $1.71 \pm 0.09^{\mathrm{e}}$ & $1.95 \pm 0.08^{\mathrm{ab}}$ \\
\hline CYS & $0.23 \pm 0.01^{\mathrm{a}}$ & $0.23 \pm 0.01^{\mathrm{a}}$ & $0.23 \pm 0.01^{\mathrm{ab}}$ & $0.22 \pm 0.01^{\mathrm{ab}}$ & & $0.23 \pm 0.02^{\mathrm{a}}$ & $0.23 \pm 0.01^{\mathrm{a}}$ & $0.22 \pm 0.01^{\mathrm{ab}}$ & $0.21 \pm 0.01^{\mathrm{b}}$ & $0.23 \pm 0.01^{\mathrm{a}}$ \\
\hline ARG & $1.28 \pm 0.02^{\mathrm{c}}$ & $1.30 \pm 0.08^{\mathrm{c}}$ & $1.32 \pm 0.11^{\mathrm{bc}}$ & $1.30 \pm 0.03^{\mathrm{c}}$ & $1.26 \pm 0.02^{\mathrm{cd}}$ & $1.38 \pm 0.03^{\mathrm{ab}}$ & $1.30 \pm 0.03^{\mathrm{c}}$ & $1.29 \pm 0.04^{\mathrm{c}}$ & $1.18 \pm 0.06^{\mathrm{d}}$ & $1.41 \pm 0.06^{\mathrm{a}}$ \\
\hline PRO & $0.78 \pm 0.02^{\mathrm{e}}$ & $0.86 \pm 0.07^{\text {bcde }}$ & $0.83 \pm 0.06^{\text {cde }}$ & $0.93 \pm 0.02^{\mathrm{b}}$ & $0.87 \pm 0.04^{\text {bcd }}$ & $0.93 \pm 0.07^{b}$ & $0.84 \pm 0.02^{\text {cde }}$ & $0.90 \pm 0.05^{\mathrm{bc}}$ & $0.81 \pm 0.05^{\mathrm{de}}$ & $1.10 \pm 0.12^{\mathrm{a}}$ \\
\hline$\Sigma \mathrm{NAA}$ & $9.94 \pm 0.02^{\mathrm{bc}}$ & $10.09 \pm 0.06^{\mathrm{b}}$ & $10.23 \pm 0.16^{\mathrm{ab}}$ & $10.24 \pm 0.04^{\mathrm{ab}}$ & $9.83 \pm 0.03^{\mathrm{bc}}$ & $10.80 \pm 0.04^{\mathrm{ab}}$ & $10.15 \pm 0.03^{\mathrm{ab}}$ & $10.07 \pm 0.06^{\mathrm{b}}$ & $9.36 \pm 0.04^{\mathrm{c}}$ & $11.26 \pm 0.08^{\mathrm{a}}$ \\
\hline $\mathrm{EA} / \mathrm{AA}^{1}$ & $45.94 \pm 1.85^{b}$ & $51.19 \pm 2.12^{\mathrm{a}}$ & $46.27 \pm 2.55^{\mathrm{ab}}$ & $38.27 \pm 3.11^{\mathrm{d}}$ & $44.80 \pm 3.27^{\mathrm{bc}}$ & $45.64 \pm 2.63^{\mathrm{bc}}$ & $45.60 \pm 3.50^{\mathrm{bc}}$ & $45.06 \pm 3.18^{\mathrm{bc}}$ & $44.81 \pm 1.68^{\mathrm{bc}}$ & $43.33 \pm 3.09^{c}$ \\
\hline EA/NAA ${ }^{2}$ & $0.85 \pm 0.01^{\mathrm{ab}}$ & $0.82 \pm 0.01^{\mathrm{b}}$ & $0.86 \pm 0.02^{\mathrm{a}}$ & $0.62 \pm 0.01^{\mathrm{d}}$ & $0.81 \pm 0.02^{\mathrm{bc}}$ & $0.83 \pm 0.03^{\mathrm{ab}}$ & $0.83 \pm 0.01^{\mathrm{ab}}$ & $0.82 \pm 0.04^{\mathrm{b}}$ & $0.81 \pm 0.02^{b c}$ & $0.76 \pm 0.05^{\mathrm{c}}$ \\
\hline
\end{tabular}

${ }^{1} \mathrm{EA} / \mathrm{AA}$, essential amino acid to total amino acid ratio.

${ }^{2}$ EA/NAA, essential amino acid to non-essential amino acid ratio.

${ }^{\mathrm{a}-\mathrm{e}}$ Means with different superscripts in the same row differ significantly $(\mathrm{p}<0.05)$.

functions ( $\mathrm{Wu}, 2010)$. In the present study, eight major EAAs including; threonine (THR), methionine (MET), valine (VAL), isoleucine (ILE), leucine (LEU), histidine (HIS), phynylalanine (PHE) and lysine (LYS) were detected in all of cuts studied. Amongst, LEU and LYS were the most predominant EAAs detected, and they presented at highest amounts in top-round. Similar to our results, those of Lorenzo and Pateiro (2013), and Franco et al. (2013) showed that the EAAs which had the higher amounts in foal's longissimus dorsi were LEU and LYS. Regarding the total EAA content, the top-round showed the highest value which was significantly $(p<0.05)$ higher than those in all of other-remaining cuts except for shank and strip-loin. For NAAs content, shank had the highest value, loin had lower and short-plate-brisket had the lowest value $(p<0.05)$. Regarding EA/AA ratio, the highest ratios were found in loin and strip-loin, and the lowest was found in shoulderchuck-roll $(\mathrm{p}<0.05)$. In addition, the EA/NAA ratio showed a highly significant difference, ranging between the cuts from 0.62 to 0.86 . Similarly Lorenzo and Pateiro (2013) also found a significant difference between the foals muscles for the EA/NAA ratios with higher values (1.03 to 1.07) compared with those in our study. However, when compared to the EA/NAA ratios $(0.81$ to 0.85$)$ reported by Franco et al. (2013) for longissimus dorsi muscle of 15-moold foals, most of cuts in the present study had similar EA/NAA ratio. From these obtained results it can be said that the differences in the amino acid contents and their ratios may be attributed due to the differences in quantity and quality of proteins between the cuts.

In conclusion, this is the first study to evaluate the chemical, meat quality and nutritional characteristics of majority of retail horse meat cuts according to the Korean Standard for retail cut trading and the carcass grading system. Type of retail cut had a significant effect on chemical composition, technological quality traits and nutritional composition of horse meat. In general, the horse meat cuts studied had the protein and fat contents similar to those of other conventional meat types published in literature. Additionally, all of horse meat cuts showed healthy nutritional profiles with high amount of traceelement (e.g., Fe), high PUFA and lower SFA contents, favorable PUFA/SFA and n-3/n-6 ratios. Therefore, the findings of the present study provide the useful information which can improve consumer's appreciation, acceptance and consumption for this meat type.

\section{CONFLICT OF INTEREST}

We certify that there is no conflict of interest with any financial organization regarding the material discussed in the manuscript.

\section{ACKNOWLEDGMENTS}

This work was supported by "Cooperative Research 
Program for Agriculture Science \& Technology Development (Project No. PJ00941703)" Rural Development Administration, Republic of Korea.

\section{REFERENCES}

American Heart Association. 2008. Heart and stroke encyclopedia. Dietary guidelines for healthy american adults. Cholesterol. Fat. http://www.americanheart.org. Accessed September 13, 2008.

AOAC. 2006. Official Methods of Analysis. 18th ed., Association of Official Analytical Chemists, Washington, DC, USA.

Aristoy, M. C. and F. Toldra. 1991. Deproteinization techniques for HPLC amino acid analysis in fresh pork muscle and dry cured ham. J. Agric. Food Chem. 39:1792-1795.

Ba, H. V., K. S. Ryu, T. K. L. Nguyen, and I. H. Hwang. 2013. Influence of particular breed on meat quality parameters, sensory characteristics and volatile compounds. Food Sci. Biotechnol. 22:651-658.

Badiani, A. and M. Manfredini. 1994. The production of horse meat. Italian J. Anim. Sci. 20:5-43.

Belew, J. B., J. C. Brooks, D. R. McKenna, and J. W. Savell. 2003. Warner-Bratzler shear evaluations of 40 bovine muscles. Meat Sci. 64:507-512.

Burdge, G. C. and P. C. Calder. 2005. Alpha-linolenic acid metabolism in adult humans: the effects of gender and age on conversion to longer-chain polyunsaturated fatty acids. Eur. J. Lipid Sci. Technol. 107:426-439.

Campo, M. D., G. Brito, J. S. D. Lima, P. Hernández, and F. Montossi. 2010. Finishing diet, temperament and lairage time effects on carcass and meat quality traits in steers. Meat Sci. 86:908-914.

Del Bo, C., P. Simonetti, C. Gardana, P. Riso, G. Lucchini, and S. Ciappellano. 2013. Horse meat consumption affects iron status, lipid profile and fatty acid composition of red blood cells in healthy volunteers. Int. J. Food Sci. Nutr. 64:147-154.

Department of Health. 1994. Nutritional aspects of cardiovascular disease (report on health and social subjects no 46). London UK: HMSO.

FAO. 2010. Top production - meat ingredients, horse. http://faostat.fao.org/site/339/default.aspx. Accessed July 12, 2010.

Faustman, C. and R. G. Cassens. 1990. The biochemical basis for discoloration in fresh meat: A review. J. Muscle Foods 1:217243.

Folch, J., M. Lees, and G. H. Sloane-Stanley. 1957. A simple method for the isolation and purification of total lipid from animal tissue. J. Biol. Chem. 26:497-507.

Franco, D. and J. M. Lorenzo. 2014. Effect of muscle and intensity of finishing diet on meat quality of foals slaughtered at 15 months. Meat Sci. 96:327-334.

Franco, D., S. Crecente, J. A. Vázquez, M. Gómez, and J. M. Lorenzo. 2013. Effect of crossbreeding and amount of finishing diet on growth parameters, carcass and meat composition of foals slaughtered at 15 months of age. Meat Sci. 93:547-556.

Franco, D., E. Rodríguez, L. Purriños, S. Crecente, R. Bermúdez, and J. M. Lorenzo. 2011. Meat quality of "Galician Mountain" foals breed. Effect of sex, slaughter age and livestock production system. Meat Sci. 88:292-298.

Gill, C. O. 2005. Safety and storage stability of horse meat for human consumption. Meat Sci. 71:506-513.

Han, G. D., D. G. Kim, S. M. Kim, D. H. Ahn, and S. K. Sung. 1996. Effects of aging on the physico-chemical and morphological properties in the Hanwoo beef by the grade. Korean J. Anim. Sci. 38:589-596.

Huff-Lonergan, E. and S. M. Lonergan. 2005. Mechanisms of water-holding capacity of meat: The role of postmortem biochemical and structural changes. Meat Sci. 71:194-204.

Hwang, I. H., B. Y. Park, S. H. Cho, and J. M. Lee. 2004. Effects of muscle shortening and proteolysis on Warner-Bratzler shear force in beef longissimus and semitendinosus. Meat Sci. 68:497-505.

JMI. 2010. Surveys on behavior of retail meat stores. Tokyo: Japan Meat Information Service Center. http://www.jmi.or.jp/info/ survey_files/file4/52.pdf. Accessed August 1, 2010.

Juarez, M., O. Polvillo, M. D. Gomez, M. J. Alcalde, F. Romero, and M. Varela. 2009. Breed effect on carcass and meat quality of foals slaughtered at 24 months of age. Meat Sci. 83:224-228.

Jump, D. B. 2002. The biochemistry of n-3 polyunsaturated fatty acids. J. Biol. Chem. 277:8755-8758.

Kratz, M. 2005. Dietary cholesterol, atherosclerosis and coronary heart disease. Handb. Exp. Pharmacol. 170:195-213.

Lepetit, J., A. Grajales, and R. Favier. 2000. Modelling the effect of sarcomere length on collagen thermal shortening in cooked meat: Consequence on meat toughness. Meat Sci. 54:239-250.

Litwinczuk, A., M. Florek, P. Skalecki, and Z. Litwinczuk. 2008. Chemical composition and physicochemical properties of horse meat from the longissimus lumborum and semitendinosus muscle. J. Muscle Foods 19:223-236.

Lorenzo, J. M., M. V. Sarriés, A. Tateo, P. Polidori, D. Franco, and M. Lanza. 2014. Carcass characteristics, meat quality and nutritional value of horsemeat: A review. Meat Sci. 96:14781488.

Lorenzo, J. M., M. Pateiro, and D. Franco. 2013. Influence of muscle type on physicochemical and sensory properties of foal meat. Meat Sci. 94:77-83.

Lorenzo, J. M. and M. Pateiro. 2013. Influence of type of muscles on nutritional value of foal meat. Meat Sci. 93:630-638.

Maeno, H., K. Oishi, T. Mitsuhashi, H. Kumagai, and H. Hirooka. 2014. Prediction of carcass composition and individual carcass cuts of Japanese Black steers. Meat Sci. 96:1365-1370.

Matilainen, R. and J. Tummavuori. 1996. Iron Determination in fertilizers by inductively coupled plasma atomic emission spectrometry: Study of spectral and interelement effects at different wavelengths. J. AOAC Int. 79:22-28.

MFDS. 1996. The Korea Standards for Meats Retail Cuts Trading. Ministry of Food and Drugs Safety, Chungcheongbuk-do, Korea.

Morrison, W. R. and L. M. Smith. 1964. Preparation of fatty acid methyl esters and dimethylacetals from lipids with boron fluoride-methanol. J. Lipid Res. 5:600-608.

Moya, V. L., M. Flores, M. C. Aristoy, and F. Toldra. 2001. Pork meat quality affects peptide and amino acid profiles during the ageing process. Meat Sci. 58:197-206.

Palo, P. D., A. Maggiolino, P. Centoducati, and A. Tateo. 2013. Slaughtering age effect on carcass traits and meat quality of 
italian heavy draught horse foals. Asian Australas. J. Anim. Sci. Sakata, R., T. Deguchi, and Y. Nagata. 1993. Effectiveness of the 26:1637-1643.

Ramos, A., M. C. Cabrera, M. del Puerto, and A. Saadoun. 2009. Minerals, haem and non-haem iron contents of rhea meat. Meat Sci. 81:116-119. filter paper press method for determining the water holding capacity of meat. Fleischwirtsch 73:1399-1400.

SAS Institute, Inc. SAS User's Guide. Release. 9.1.3. 2007. Statistical Analysis System Institute. Cary, NC, USA.

Rhee, K. I., T. R. Dutson, and G. C. Smith. 1982. Effect of changes in inter-muscular and subcutaneous fat levels on cholesterol content of raw and cooked beef steaks. J. Food Sci. 47:1638-1642.

Sekar, A., K. Dushyanthan, K. T. Radhakrishnan, and R. Narendra Babu. 2006. Effect of modified atmosphere packaging on structural and physical changes in buffalo meat. Meat Sci. 72:211-215.

Sarriés, M. V., B. E. Murray, D. Troy, and M. J. Beriain. 2006. Intramuscular and subcutaneous lipid fatty acid profile composition in male and female foals. Meat Sci. 72:475-485.

Sarriés, M. V. and M. J. Beriain. 2005. Carcass characteristics and meat quality of male and female foals. Meat Sci. 70:141-152.

Sarriés, M. V. and M. J. Beriain. 2006. Colour and texture characteristics in meat of male and female foals. Meat Sci. 74:738-745.

Tateo, A., P De Palo, E. Ceci, and P. Centoducati. 2008. Physicochemical properties of meat of Italian Heavy Draft horses slaughtered at the age of eleven months. J. Anim. Sci. 86:1205-1214.

Tapiero, H, Tew KD. 2003. Trace elements in human physiology and pathology: zinc and metallothioneins. Biomed. Pharmacother. 57:399-411.

Wu, G. 2010. Functional amino acids in growth, reproduction, and health. Adv. Nutr. 1:31-37. 